
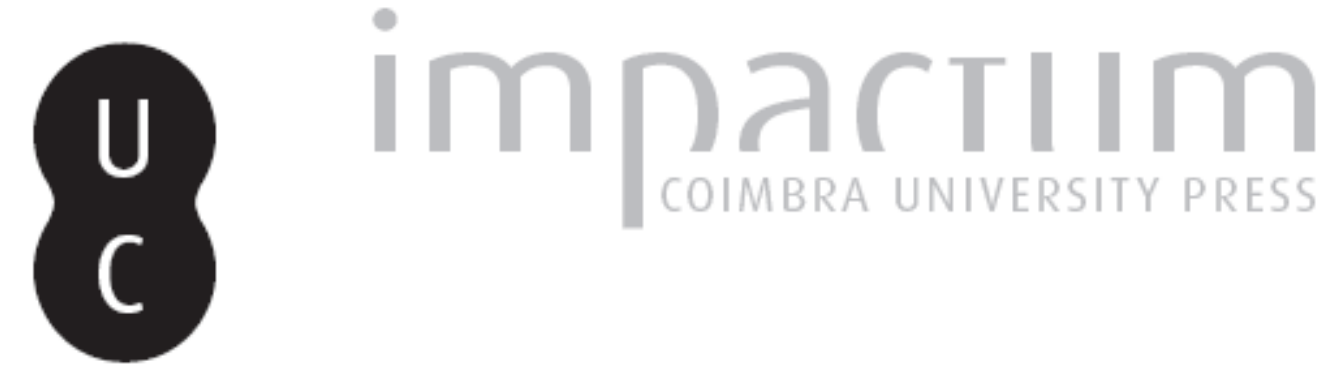

No septuagésimo aniversário da Revista Portuguesa de História: evocação

Autor(es): $\quad$ Veloso, Maria Teresa Nobre Publicado por: $\begin{aligned} & \text { Faculdade de Letras da Universidade de Coimbra, Instituto de História } \\ & \text { Económica e Social }\end{aligned}$

URL persistente:

URI:http://hdl.handle.net/10316.2/28014

DOI:

DOI:http://dx.doi.org/10.14195/0870-4147_42_17

Accessed : $\quad$ 26-Apr-2023 14:08:58

A navegação consulta e descarregamento dos títulos inseridos nas Bibliotecas Digitais UC Digitalis, UC Pombalina e UC Impactum, pressupõem a aceitação plena e sem reservas dos Termos e Condições de Uso destas Bibliotecas Digitais, disponíveis em https://digitalis.uc.pt/pt-pt/termos.

Conforme exposto nos referidos Termos e Condições de Uso, o descarregamento de títulos de acesso restrito requer uma licença válida de autorização devendo o utilizador aceder ao(s) documento(s) a partir de um endereço de IP da instituição detentora da supramencionada licença.

Ao utilizador é apenas permitido o descarregamento para uso pessoal, pelo que o emprego do(s) título(s) descarregado(s) para outro fim, designadamente comercial, carece de autorização do respetivo autor ou editor da obra.

Na medida em que todas as obras da UC Digitalis se encontram protegidas pelo Código do Direito de Autor e Direitos Conexos e demais legislação aplicável, toda a cópia, parcial ou total, deste documento, nos casos em que é legalmente admitida, deverá conter ou fazer-se acompanhar por este aviso.

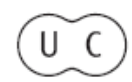





\title{
No septuagésimo aniversário da Revista Portuguesa de História - evocação
}

\author{
Maria Teresa Nobre Veloso \\ Faculdade de Letras da Universidade de Coimbra \\ Centro de História da Sociedade e da Cultura - FLUC \\ mtnveloso@fl.uc.pt
}

O tomo 42 da Revista Portuguesa de História pretende associar-se à celebração do primeiro centenário da Faculdade de Letras, que ocorre neste ano de 2011. Porém, o presente volume assinala igualmente sete décadas de investigação histórica no nosso país.

Fundada pelo Prof. Torquato de Sousa Soares, e diligentemente continuada até 1993 pelo Prof. Luís Ferrand de Almeida, a primeira das Revistas de História publicada em Portugal surge em 1941, subsidiada pelo Instituto para a Alta Cultura. Destinava-se aquela, como pode ler-se na nota da redacção que abre o primeiro volume, "a ser o testemunho vivo da actividade cultural do Instituto de Estudos Históricos e a projecção dessa actividade em todo o país". Mas não só em Portugal como especialmente e em particular no estrangeiro, como pode ler-se ainda na referida nota da redacção, "procurará a Revista Portuguesa de História pôr-se desde já em contacto com os diversos países da Europa e da América dando a conhecer por seu intermédio (...) os resultados da sua actividade científica". Era um plano ambicioso tendo em conta os anos sombrios de guerra que então se viviam em todo o mundo.

Em 1975, o Instituto de Estudos Históricos passou a designar-se Instituto de História Económica e Social e, no ano seguinte, o volume 16 manifesta já essa realidade. Os objectivos traçados e alcançados pelos pioneiros intensificaram-se a partir da década de 70, quando o corpo docente do referido Instituto se alargou de modo significativo. Na verdade, a Revista Portuguesa de História reflecte não só a investigação produzida por todos os Professores do Instituto de História Económica e Social, mas também a de todos os membros do Grupo de História, distribuídos pelos diversos Institutos da área - Arqueologia, História da Arte, Expansão, Teoria das Ideias e Paleografia - e ainda por outros Institutos da nossa Faculdade.

Além disso, são inúmeros os valiosos artigos vindos de todo o país que a Revista tem acolhido e que o presente volume uma vez mais documenta. 
Provêm, não só de docentes das Faculdades de Letras de Lisboa e do Porto, mas também das Faculdades de Direito e de Economia das Universidades de Lisboa e de Coimbra, bem como de outros distintos investigadores filiados noutras instituições científicas.

Soma-se aos referidos contributos, as colaborações que, ao longo destes 70 anos, têm chegado à nossa Revista subscritos pelos mais notáveis professores estrangeiros - Claudio Sanchez Albornoz, Justo Perez de Urbel, Emílio Saez, Manuel Diaz y Diaz, Charles Verlinden, Yves Renouard, Albert Silbert, Michel Vouvelle, Harold Livermoor, Charles Boxer e tantos outros, a acrescentar àqueles que nos deram a honra de colaborar neste volume, cuja lista exaustiva seria despropositado aqui apresentar, mas que são um indeclinável convite à nossa curiosidade de leitores e de estudiosos.

O valor da Revista Portuguesa de História patenteia-se e enriquece-se sobremaneira no número de permutas que regularmente mantém e que lhe proporcionam uma visibilidade inquestionável - 80 nacionais e 66 estrangeiras, às quais se deve acrescentar os 58 assinantes estrangeiros. Assim, esta Revista está presente nas principais bibliotecas universitárias da Europa (Alemanha, Bélgica, Espanha, França, Inglaterra, Itália, Países Baixos, Roménia e Rússia) e das Américas (Estados Unidos e México, bem como Argentina e Brasil). A estes números, que mostram bem quanto a nossa Revista "é o testemunho vivo da actividade cultural do Instituto e a projecção dessa actividade", como em 1941 escrevia a Redacção que já citámos, acresce ainda uma centena de volumes que são distribuídos como oferta pessoal e institucional. É esta visibilidade que justifica que vários números estejam esgotados.

Apesar de septuagenária, e sem perder a sobriedade que a caracteriza, a Revista Portuguesa de História mantém a frescura que o novo design gráfico das suas capas e a adopção das normas internacionais da edição de periódicos documentam.

Ao longo de sete décadas a Revista Portuguesa de História, que publicou em 42 volumes (alguns deles duplos) cerca de vinte mil páginas de texto, foi acompanhando as exigências dos tempos, mas o lema continuou a ser aquele que ostentava o timbre do ex-libris do Instituto de Estudos Históricos de que o Instituto de História Económica e Social teve o privilégio de ser o continuador: "Interroga et diligenter investiga". 